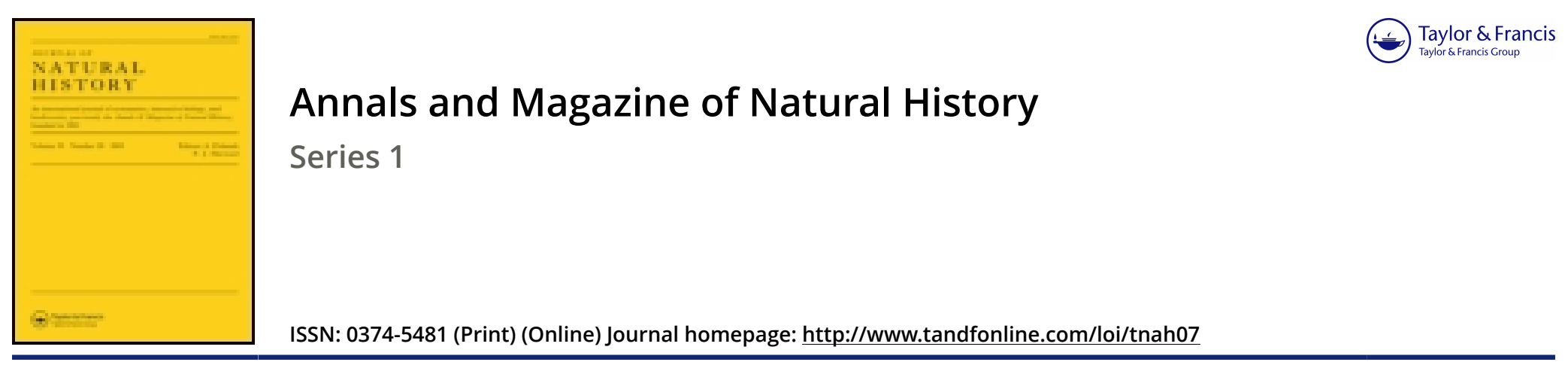

\title{
On the genus Pedicularia or Thyreus
}

\author{
J. E. Gray
}

To cite this article: J. E. Gray (1846) On the genus Pedicularia or Thyreus, Annals and Magazine of Natural History, 18:121, 428-429, DOI: 10.1080/037454809494449

To link to this article: http://dx.doi.org/10.1080/037454809494449

册 Published online: 10 Dec 2009.

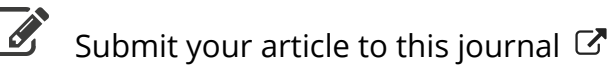

Q View related articles $₫$ 
range of medicines to ring the changes upon. No Geranium has now a place in any British Pharmacopcia*, but several species hold a conspicuous place in the old Herbals. Of Geranium pratense and its immediate allies, Gerarde says, " none of these plants are now in vse in physicke; yet Fuschius sayeth that cranes-bill with the blew floure (G.pratense) is an excellent thing to heale wounds." Our author speaks in very different terms of our commoner species, Ger. molle and dissectum. "The herbe and roots dried," says he, " beaten into most fine powder, and given halfe a spoonful fasting, and the like quantitie to bedwards in red wine, or old claret, for the space of one and twentie days together, cureth miraculously ruptures or burstings, as myselfe have often proved, whereby I haue gotten crownes and credit: if the ruptures be in aged persons, it shall be needfull to adde thereto the powder of red snailes (those without shels) dried in an ouen, in number nine, which fortifie the herbs in such sort, that it neuer faileth, although the rupture be great and of long continuance : it likewise profiteth much those that are wounded into the body, and the decoction of the herbe made in wine, prevaileth mightily in healing inward wounds, as myselfe haue likewise proved."-Historie of Plants, p. 939.

Ray also furnishes us with a proof of the medicinal virtue of the Gerania. When he tells us that Geranium molle and robertianum are added to vulnerary potions and fomentations to stay fluxes and effusions of blood, and to relieve the pains of colic, and of the stone and gravel, he merely gives us a summary of preceding observation; but he speaks from his own knowledge when he details the case of his host at Carlisle, who, subject to frequent severe paroxysms of pain from calculus, found in nothing so much relief as from a decoction of Ger. robertianum. (Syn. p. 361.) In a subsequent work, after repeating its virtues as a vulnerary herb, Ray mentions that a decoction of the same species is used by shepherds to cure their cattle passing bloody urine. (Hist. Plant. ii. p. 1059.)

Geiger informs us that G. pratense and sanguineum were formerly officinal, the root and herb being used, both having an unpleasant odour and a very astringent taste, which is contrary to Dr. Edgar's information. Other compilers repeat the same tale th of the astringency of the Gerania in general, and of their popular use in fluxes and diseases of relaxation; but it is foreign to my purpose to enter farther on the subject than what is sufficient to show that the virtue ascribed to our district species is not imaginary.-From the Transactions of the Berwickshire Naturalists' Club, vol. ii. p. 175.

\section{ON THE GENUS PEDICULARIA OR THYREUS.}

Mr. Swainson, in 'Lardner's Ency.'’ pp. 240, 245, 357, fig. 44, applied the former name to a small rosy shell found on coral at Sicily, which he arranges with the Patell $c$, and it has been retained in that

* Several Gerania are introduced into Dr. Stokes's ' Botanical Materia Medica,' but without any indication of their properties.

$\dagger$ For extracts from the works of L. Mérat, Geiger and Gerbuier, I am indebted to the obliging kindness of Professor Christison. 
family by all succeeding authors. Philippi also describcd and figured it as new under the name of Thyreus Paradoxus, Supp. 92. t. 18. f. 11 .

Having lately obtained a fresh specimen with the animal dried in it, I soaked it in water, and on comparing the remains of the animal with other genera, I believe that the Pedicularia of Swainson should be placed next to Concholepas, if it is more than a section of that genus, for it only differs from that genus in having no tooth-like process on the front of the outer lip, and in the edge of the outer lip being generally sinuous, and the inner or columellar lip being rounded, callous, and covering part of the left side of the last whorl. There is a small white shell in Mr. Cuming's collection from the Philippines which has similar characters, but it is even more like the typical Concholepas than Pedicularia Sicula of Swainson.-J. E. GRAY.

\section{Descriptions of some new species of Indian Lizards. By J. E. Gray, Esq.}

Mr. Jerdon of Madras having kindly sent to the Museum a series of specimens of Indian reptiles, I hasten to describe the following species, which have not before occurred to me, and consequently are not described in my recent Synoptic Catalogue of Reptiles in the British Museum.

\section{Fam. Grckotide.}

Goniodactylus indicus.-Brown, darker marbled and spotted; scales of body and tail small, equal, six-sided; of underside of tail rather larger, six-sided; lower lip-shield $5 \cdot 1 \cdot 5$, square, front larger, equal, rest gradually smaller, last very small.

Hab. Madras. Brit. Mus.

These were accompanied by four species of Hemidactylus.

Fam. Agamida.

Calotes viridis. Nape with two isolated spines above the ears. Neck without any pit in front of the shoulder, but with dark spots at the hinder part of the lower jaw ; eyebrows not horned. Green; scales large, of base of tail larger, of limbs and underside of the body smaller, of crown smaller. Nape and shoulders with a compressed crest; hinder part of back and tail with an obscure keel.

Hab. Madras. Brit. Mus.

Like $C$. versicolor, but uniformly coloured, the back less crested, and the scales smaller.

Salea Jerdonii. The nuchal and dorsal crest formed of elongated compressed scales; tail with a keeled crest. Blackish, white spotted, spot forming distant cross-bands; lips and beneath white.

Hab. Madras. Brit. Mus.

This genus is best distinguished from Calotes by the length and acuteness of the keeled scales of the back, side and under part of body, and their being all placed in longitudinal series. 'The other species has only the nape shortly crested. 